\title{
Italian Musicians in Francoist Spain, 1939-1945: The Perspective of Music Critics
}

\section{EVA MOREDA-RODRÍGUEZ}

In May 1939, after nearly three years of civil war, the musical life of Spain was devastated, as was the country at large. Some of the leading names of the musical and musicological renovation of Spain of the prior decades went into exile for political or financial reasons; some of the most active ensembles and orchestras had also suffered disintegration and disorganization. 'This situation was mirrored in almost all the other artistic and intellectual circles of the nation. The self-proclaimed 'liberation Crusade' initiated by General Francisco Franco in 1939 to save Spain from Bolshevism had resulted in the birth of the Nuevo Estado, a 'new state' that had to be thoroughly reconstructed and redefined by the victorious side-not only physically, but also ideologically and culturally.

Within this context, this article aims to analyze one of the most significant elements of the musical life of the country during the post-Civil War and World War II years (1939-1945): musical exchanges with Italy and their representation in the press of the time. Specifically, I will analyze how the visits of Italian musicians were received by Spanish music critics using two pairs of contrasting parameters: modern-traditional and national-foreign. This analysis will be preceded by a historical contextualization of the diplomatic relations and musical exchanges within the Axis. Finally, I will focus on Italian opera since discourse about the genre reflects in interesting ways the lack of a coherent musical policy during this period and the contradictions that arose as a consequence. Although Spanish critics suggested that opera was a threat to Spain's musical essence during the 19th century, it enjoyed a remarkable popularity that was used to some extent by the regime for political and financial purposes.

The Spanish musical life of the immediate post-Civil War years has received little specific attention from scholars, and the importance of musical exchanges with the Axis countries has often been reduced to vague references to propagandistic aims, or even ignored completely. ${ }^{2}$ None of the

\footnotetext{
${ }^{1}$ Among those who went into exile during the Civil War were the musicologists and critics Adolfo Salazar and Jesús Bal y Gay, the composers Roberto Gerhard, Salvador Bacarisse, Rodolfo Halffter, and Julián Bautista, and the cellist Pau Casals. Manuel de Falla, the Spanish composer who enjoyed an international reputation and whom the Franco regime quickly identified as an invaluable asset for its own prestige, left in fall 1939 for Argentina, where he would die seven years later without ever having returned to his home country. For a complete discussion of Falla's complex position during the Civil War and the years of his exile, see Carol A. Hess, Sacred Passions: The Life and Music of Manuel De Falla (Oxford: Oxford University Press, 2005), 213-283.

${ }^{2}$ See, for example, Javier Suárez-Pajares, ed., Música Española Entre Dos Guerras (Granada: Archivo Manuel de Falla, 2002). On page 13, Suárez-Pajares makes only a brief reference to the visits of the Berliner Philharmonie to Spain in the 1940s and their propagandistic mission. The volume includes a study of British-Spanish musical exchanges during World War II (Samuel Llano, "Walter Starkie y el British Council en España. Música Cultura y Propaganda,” in op. cit, 187217) that reveals that the Allies also tried to use musical and cultural exchanges to counterbalance the influence of Axis powers, but the study does not deal with any aspects of the relations of Spain and the nations it befriended during the same period.
} 


\section{Music AND Politics Winter 2008}

chapters of the most recent comprehensive volume about Spanish music of the 1940s are devoted to assessing the role of international exchange in the musical life of Spain during this era.

In the last five years, two studies focusing specifically on Italian-Spanish musical relations have appeared, both by Gemma Pérez Zalduondo. However, her research either gravitates toward a single composer (Alfredo Casella) without giving the reader a complete picture (the implications of Casella's visit to Madrid in 1942, for example). Alternatively, it encompasses a period of time broader than the World War II years but without detailed comparison of continuities or discontinuities between post-Civil War musical exchanges and those that had begun in the years of the Second Republic (1931-1939). ${ }^{5}$ Although exchanges with Germany were far more numerous and sustained than those with Italy (as suggested by the evidence found in the musical press and newspapers of the time) no specific study of the musical relations of Spain with the Nazi regime has yet been published.

\section{Historical context: the Spanish Civil War and World War II}

The rhetoric of the Nuevo Estado and the rebirth of Spain after the Civil War can be associated specifically with one of the several factions that supported Franco: Falange Española, identifiable as the Spanish fascist party, which became the main power within the government during the first years of the regime and effectively controlled cultural and intellectual life, press, and propaganda. ${ }^{6}$ The political pre-eminence of the Falange largely determined the position of Spain during the first years of World War II. The Falange had already established contacts with the Fascio and Nazi parties before 1936, and both governments had supported Franco's military during the Spanish Civil War. Although Spain never entered World War II officially, modern historiography has revealed that Franco seriously considered entering the struggle on at least two occasions; moreover, the official rhetoric was pro-Axis and rich in Fascist elements. The situation changed towards the summer of 1942, when the difficulties encountered by Germany on the Eastern Front started to spread doubt about an Axis victory. As a result, Franco adopted a more cautious foreign policy and eventually, when the war was almost over, sought to convince the Allies that the Spanish regime was not in the least Fascist. ${ }^{7}$

This evolution was mirrored to some extent in the musical exchanges with Germany and Italy, with a concentration of the most significant events-the three Hispanic-German music festivals or

\footnotetext{
${ }^{3}$ Javier Suárez-Pajares, ed., Joaquín Rodrigo y la Música Española De los Años Cuarenta (Valladolid: Glares, 2005). "Gemma Pérez Zalduondo, "Alfredo Casella e la Musica Italiana in Spagna (1915-1945)," Chigiana 44 (2003): 379-397. ${ }^{5}$ Gemma Pérez Zalduondo, "Música y Músicos Italianos En España (1931-1943),” Speculum Musicae 10 (2004): 65-94. ${ }^{6}$ In order to understand the evolution of cultural and musical life during the Franco regime, it is important to take into account the fact that Franco's government was formed by representatives of various factions (the Church, the army, monarchists, Carlistas, etc.), not all of which shared the aim of transforming Spain radically into a national-syndicalist state, as was the objective of the Falange, fascist in its palingenetical objectives (for an explanation of "palingenesis" see Roger Griffin, "Fascism," in The Blackwell dictionary of twentieth-century social thought, ed. William Outhwaite and Tom Bottomore (Oxford: Blackwell, 1993), 223-224.

${ }^{7}$ For an analysis of the relations of Franco's Spain with the Axis, see Paul Preston, The Politics of Revenge: Fascism and the Military in Twentieth-Century Spain (London: Unwin Hyman 1990), 51-84 and by the same author "Franco's Foreign Policy 1939-1953," in Spain in an International Context, 1936-1959, ed. Christian Leitz and David J. Dunthorn, 1-17 (New York: Berghahn Books, 1999).
} 
the visit of composer Alfredo Casella to Spain, for example-before the summer of $1942{ }^{8}$ Musical exchanges continued, however, well beyond the phase of strong political connections between the Franco government and the two big fascist regimes. Indeed, the fact that musical relations with Germany and Italy were maintained until a rather late phase of the war (fall 1944) suggests that their interruption was due to the critical military situation of the Axis powers rather than a desire on either side to end diplomatic and cultural relations, even after the possibility of Spain entering the war had vanished.

\section{Musical exchanges: actors and objectives}

The musical exchanges of Spain with Italy and other countries during this period were not part of a unified, systematic program put in place by a centralized body. Indeed, there were a number of organizations and institutions aiming to assure the presence of Spanish performers abroad and vice versa. The Fascio established a focus of propaganda and culture in Spain in 1940 by opening an Institute of Italian Culture, which was based in Madrid with subsidiaries in a further ten cities of cultural significance. The Italian Embassy was active in assisting the Institute in the organization of musical events, as was the Liceo Italiano, an educational structure based in Spain that hosted the children of Italian citizens.

On the side of Spain, the institutions most concerned with musical exchanges with the Axis were, not coincidentally, those controlled by the Falange in either the Franco government (the Delegation of Propaganda and the Ministry of Foreign Affairs) and the trade union (the Asociación de la Prensa, or press association, the Sindicato Español Universitario, or students' union, and Educación y Descanso), or those directly integrated within the structure of the party (the Vicesecretaría de Educación Popular). ${ }^{9}$ Although not directly under Falangist control, the Commission of Music, directed by composer Joaquín Turina, also played a major role in the exchanges.

Some of these events were rather modest cultural exchanges with relatively little symbolism, but others involved elements that stressed their political and military significance. The most common of these elements was the presence of high-ranking members of the Spanish and Italian governments or of the Falange (and on limited occasions, the Catholic Church), sometimes with one or several of them delivering a speech during the event. The objectives of these events, however, went beyond the symbolic reinforcement of political alliances. Sometimes they were also financial and aimed at supporting the war effort-both the troops who were fighting in World

\footnotetext{
${ }^{8}$ The Hispanic-German music festivals were held in July 1941 in Bad Elster (Saxony, Germany), in January 1942 in Madrid and Bilbao (Spain), and again in Bad Elster in July and August 1941.

${ }^{9}$ Educación y Descanso means literally 'Education and Leisure.' This department-a subset of the apparatus of the Falange-was in charge of propaganda, culture, and leisure activities aimed at the working classes. Musically, its most important contribution was creating and maintaining a number of choral societies around the country. Vicesecretaría de Educación Popular was a subset of the Ministry of National Education devoted to the development of propagandistic activities and controlled by the Falange, comparable to the German Reichminister für Volksaufklärung und Propaganda or the Italian Ministerio della Cultura Popolare (MinCulPop).
} 
War II and those who had fought in the Spanish Civil War. This is the material and political context in which the events listed in Table I must be regarded.

Apart from their propaganda aims, exchanges involving musical traditions that were regarded as more prestigious played an important role in the process of the cultural and musical redefinition of Spain that was taking place. The inspiration of foreign models was by no means new and can be traced back to a humanistic trend at the end of the 19th century, when members of Spain's intelligentsia set about defining the identity and essence of the country. ${ }^{10}$ France was the model preferred by some of the most influential philosophers of the first two decades of the 20th century, such as Ramiro de Maeztu and José Ortega y Gasset, while another faction, which counted composer Conrado del Campo among its most prominent representatives, looked to Berlin and Vienna." The outbreak of World War II tipped the balance decidedly in favor of the Germanic tradition and, to a more limited extent, the Italian one as well.

\section{The national versus the foreign}

The presence of Italian music and musicians allowed critics to develop a new rhetoric that was largely unavailable to Germans: the racial connections between Spain and Italy, which shared Roman roots, and the reflection of Latin traits in art. ${ }^{12}$ The initial contacts of Falange in the late 1920s and early 1930s had been oriented towards the Fascio rather than to the Nazi party, and fascist ideologues of the Falange, such as Ernesto Giménez Caballero, had identified fascism as the "new Catholicism," thus enhancing the idea of Rome as the new center of the fascist universe. The origins of fascism were traced by Giménez Caballero back to the times of the Roman Empire, with crucial figures such as Seneca anticipating fascist theories in their writing. Thus, Caballero highlighted the racial links between Italy and Spain, making them the basis for the new, fascist world order. $^{13}$

Musical criticism of the time was influenced by such ideas, something that is exemplified by way the daily press treated composer Alfredo Casella's visit to Madrid in April 1942. Writing for the Falangist newspaper Arriba, critic Federico Sopeña portrayed Casella as a hero who had been

\footnotetext{
${ }^{10}$ The Generation of '98 was a group of Spanish poets, novelists, essayists, and philosophers active in the first decades of the 20th century in Spain. Their name is a reference to the Spanish-American war that took place in 1898, causing the loss of the last Spanish colonies (namely, Cuba, Puerto Rico, and the Philippines) and provoking a deep moral, social, and political crisis in the Spanish population. They aimed to identify the national essence of Spain by researching her history and traditions, but at the same time attempted to adapt to Spain the main philosophical trends of European Irrationalism. "The influence on the musical circles of the intellectual debate in Spain in the first decades of the 20th century has not recently received in-depth attention from the scholarly community. Some attention has been devoted to this issue in the past by Emilio Casares Rodicio, "Manuel De Falla y Los Músicos De La Generación Del 27," in Manuel De Falla Tra La Spagna e l'Europa: Atti Del Convegno Internazionale Di Studi (Venezia, 15-17 Maggio 1987), ed. Paolo Pinamonti (Firenze: Olschki, 1989), 49-63; and Jorge De Persia, “Falla, Ortega y la Renovación Musical,” Revista De Occidente 187 (1994): 102-116.

${ }^{12}$ In fact, the Italian-Spanish musical exchanges of this period are basically limited to visits of Italian performers to Spain: Spanish composers and performers tended to travel to Germany rather than to Italy, according to information gathered in the newspapers and music periodicals of the time.

${ }^{13}$ See Ernesto Giménez Caballero, La Nueva Catolicidad (Madrid: La Gaceta Literaria, 1933).
} 


\begin{tabular}{|c|c|}
\hline Month/Year & Event \\
\hline 1940 & Pianist Arturo Benedetti Michelangeli \\
\hline October 1940 & Violinist Carlo Felice Cillaro with the Orquesta Sinfónica \\
\hline December 1940 & Cellist Antonio Janigro at the Institute of Italian Culture \\
\hline January 1941 & $\begin{array}{l}\text { Opera season in Madrid with a number of Italian singers conducted by Guiseppe Podestà: Maria } \\
\text { Laurenti, Ugo Novelli, Enzo del Muro, Irma Colasante, Fernanda Basile, Florenzo Tassi, } \\
\text { Germana di Giulio, Francesco Merli and others }\end{array}$ \\
\hline January 1941 & $\begin{array}{l}\text { Spanish and Italian (Di Giulio, Merli, etc.) collaborate in the first "Concierto de empresa" } \\
\text { organized jointly by Educación y Descanso and the Italian Dopolavoro }\end{array}$ \\
\hline February 1941 & Violinist Lilia D'Albore at the Institute of Italian Culture \\
\hline February-April 1941 & $\begin{array}{l}\text { Pianist Arturo Benedetti Michelangeli offers several concerts in Madrid, including soloist } \\
\text { apparitions with the Orquesta Filarmónica and Orquesta Sinfónica }\end{array}$ \\
\hline March 1941 & Violinist Attilio Ranzato in several concerts, including one at the Institute of Italian Culture \\
\hline May 1941 & $\begin{array}{l}\text { Opera season conducted by Giuseppe Podestà with several Italian singers including Antonio } \\
\text { Salvarezza, Domenico Malatesta, Fernanda Basile, Maria Benedetti, Ugo Novelli and others }\end{array}$ \\
\hline October 1941 & Poltronieri Quartet at the Institute of Italian Culture (Madrid) and in San Sebastián \\
\hline November 1941 & Violinist Vittorio Brero as concertino of the Berliner Kammerorchester in Madrid and Bilbao \\
\hline $\begin{array}{l}\text { November-December } \\
1941\end{array}$ & $\begin{array}{l}\text { Violinist Giorgio Ciompi in several concerts in Madrid, one of them at the Institute of Italian } \\
\text { Culture. He appeared also in San Sebastián }\end{array}$ \\
\hline December 1941 & Singer Tito Schipa with the Berliner Kammerorchester \\
\hline March 1942 & Talk on Neapolitan instrumental music by Ippolito Galante at the Institute of Italian Culture \\
\hline March 1942 & $\begin{array}{l}\text { Some Italian singers take part in the opera seasons of Madrid and Seville, including Salvatore } \\
\text { Romano, Fernanda Basile, Germana di Giulio, Irma Colassante, Luigi Borgonuovo }\end{array}$ \\
\hline April 1942 & $\begin{array}{l}\text { Composer Alfredo Casella conducts the Orquesta Nacional performing his own Symphony. He } \\
\text { also appears with his Trio Italiano (together with cellist Arturo Bonucci and violinist Alberto } \\
\text { Poltronieri) and offers talks on Italian music. The Trio visited San Sebastián as well }\end{array}$ \\
\hline August-September 1942 & $\begin{array}{l}\text { The summer festival Quincena Musical held in San Sebastián features singers Giacomo Lauri- } \\
\text { Volpi and Gina Cigna. Arturo Benedetti Michelangeli and Giorgio Ciompi were also expected to } \\
\text { attend but later on they cancelled their concerts }\end{array}$ \\
\hline October 1942 & Trio di Trieste visits Madrid and San Sebastián \\
\hline November 1942 & Singers Toti Dal Monte and Augusto Beuf in a recital \\
\hline January 1943 & Napoleone Annovazzi conducts the Orquesta Bética de Cámara in Seville \\
\hline March 1943 & $\begin{array}{l}\text { Ferruccio Agosti, head of the Liceo Italiano in Madrid, offers a talk on instrumental Italian music } \\
\text { (16th to 18th century) at the Institute of Italian Culture }\end{array}$ \\
\hline April-May 1943 & $\begin{array}{l}\text { Napoleone Annovazzi conducts a season of Italian opera including Italian singers such as Gina } \\
\text { Cigna and Tito Schipa }\end{array}$ \\
\hline May 1943 & $\begin{array}{l}\text { The Orchestra of the Conservatory San Pietro a Maiella (Naples) offers } 28 \text { concerts in different } \\
\text { Spanish cities conducted by Adriano Lualdi }\end{array}$ \\
\hline August 1943 & $\begin{array}{l}\text { The orchestra and ballet of the Theatre of Rome takes part at the opera season of the Quincena } \\
\text { Musical in Sebastián, under the direction of Tulio Serafin and Napoleone Annovazzi }\end{array}$ \\
\hline February-March 1944 & $\begin{array}{l}\text { Tenor Giacomo Lauri Volpi and bass Augusto Beuf take part in the opera season together with } \\
\text { Spanish singers }\end{array}$ \\
\hline February 1944 & Napoleone Annovazzi offers a talk on Italian polyphony at the Institute of Italian Culture \\
\hline July 1944 & $\begin{array}{l}\text { The Ambassador of Italy in Spain offers Nemesio Otaño, principal of the Conservatory of } \\
\text { Madrid, the complete works of Monteverdi edited by Franceso Malipiero and printed by } \\
\text { Gabriele D'Annunzio }\end{array}$ \\
\hline
\end{tabular}

Table I: Italian musicians in Spain, 1939-1945. This list of events is by no means exhaustive and is only intended to provide the reader with a general overview of the number and nature of musical exchanges involving Spain and Italy. The list has been compiled from the six newspapers of national importance in Spain at that time (namely $A B C, E I A l c a ́ z a r$, Arriba, Informaciones, Pueblo, Ya). It is assumed that all events were held in Madrid unless otherwise indicated. 


\section{MUSIC AND POLITICS Winter 2008}

able to resist the "temptation" of atonalism because of "his desire, so Latin in essence, for clear lines and strict forms." "Almost a year later, poet and musicologist Gerardo Diego regarded Casella's music as pervaded by an "Italianity" that "beats on our Spanish hearts with rhythms, melodies and accents so utterly ours that sometimes we could not tell whether we are listening to Italy's or to Spain's song." ${ }^{15}$

Casella, in his talk at the Institute of Italian Culture on the occasion of this same visit, also provided critics with an important figure who acted as a bridge between both musical traditions: Domenico Scarlatti, who, having been born in Naples and having spent a significant part of his career in Spain, could rightly be claimed as a national composer of both Spain and Italy. ${ }^{16}$ In his review, Sopeña claimed that Scarlatti "gained his prodigious artistic personality thanks to his contact with the Spanish and the Portuguese world." ${ }^{\prime 7}$ Thus the essence of Scarlatti's compositional nature was a blending of three traditions: Italian, Spanish, and Portugese.

However, despite these racial linkages, Italian music could also be rendered foreign when Spanish critics needed to accommodate the official vision of the history of Spanish music encouraged by the Franco regime. ${ }^{18}$ In histories of music and musical criticism of the time, an idea originally formulated by musicologist and composer Felipe Pedrell at the end of the $19^{\text {th }}$ century is much in evidence: after glorious centuries of polyphony, Spain had nearly succumbed to the pervasive influence of Italian opera. In particular, Italian opera was blamed for having ruined the Spanish dramatic genre par excellence, the zarzuela. Thus, in his Historia de la música española of 1953, José Subirá favored purely 'national' composers over those who exhibited Italian influence:

Some of the composers who had been trained outside Spain and had had contacts with the foreign production wrote more distinguished compositions, but their unnatural and feigned nature deprived them of every nice spontaneity and condemned them to be only briefly famous. ... Who could forget the popular songs of Manuel García or Sebastián Iradier, which, even being simple in their writing and poor in their harmonization, contain typical Spanish or colonial spices?

Thus, Spanish musicians who had dared to oppose the Italian hegemony and chose to compose specifically Spanish music were unreservedly praised. For example, critic Víctor Espinós privileged Sebastián Iradier's "popular Hispanic songs, which challenged the bandstands, where Italianism dominated alone, as in the concerts and the stages, opposing the foreign for the national." ${ }^{19}$ Espinós thus recognized the Italian tradition not only as one that was foreign but also potentially detrimental to Spain's musical essence.

\footnotetext{
${ }^{14} 4 / 24 / 42$.

${ }^{15}$ Arriba, 2/13/43.

${ }^{16}$ As Scarlatti had also spent some time in the royal court of Lisbon, his name ensured a further connection with a third country within the Axis environment: Portugal.

${ }^{17}$ Arriba, 4/25/42.

${ }^{18}$ Whereas the day-to-day evolution of musical life was entrusted to the Comisaría de Música (Commission of Music, founded in 1939), the Instituto Español de Musicología (Spanish Institute of Musicology, founded in 1944 as part of the Consejo Superior de Investigaciones Científicas and directed by Higinio Anglés) was in charge of undertaking archival and field research of Spanish ancient and folk music, aiming to complete the project formulated in the late 19th century by Felipe Pedrell. An examination of the publications of the Instituto during the 1940s (the periodical Anuario Musical, the first volumes of the monumental edition Monumentos de la Música Española) shows an almost exclusive focus on pre18 th century and folk music.
}

${ }^{19} A B C, 2 / 7 / 44$. 


\section{The traditional versus the modern}

This dual vision of Italian and Spanish music (either as two realities that were deeply linked, or as separate elements that could contaminate each other) determined the construction of a somewhat biased concept of tradition as it figured in Italian music. What was appreciated by Spanish critics as innovative, modern, and subversive in Casella, was his contempt for bel canto and the return to what he perceived as the purest Italian tradition: pre-19th century music, particularly instrumental music. On the occasion of Casella's visit to Madrid, critics emphasized both his "audacity" and his respect for tradition as being two sides of the same coin. ${ }^{20}$ Federico Sopeña wrote that Casella's goal was "to demonstrate to the world that Italian music can be more than submission to melodrama." "Joaquín Rodrigo highlighted that Italian symphonism "is currently up and standing thanks to the understanding and the support of the government.. ${ }^{, 22}$ And Regino Sáinz de la Maza emphasized the efforts of the "three or four men" (in obvious reference to the other members of the Generazione dell'Ottanta) who were fighting for the restoration of Italian ancient instrumental tradition. $^{23}$

A further example can be found in a series of articles composer and critic José Forns published between 1941 and 1942 in the Falange organ Radio Nacional. Forns's goal, outlined in the introductory article, was to present Spanish readers with a picture of the "modern Italian renaissance." ${ }^{24}$ Forns emphasized the contempt of the new generation of composers for both "intellectualism" and the "vain operatic affectation," and their respect of their "ethnical peculiarities," which included, for example, melodies full of chiaroscuri, "which is a most Latin, Mediterranean feature." After this introductory article, the series featured individual profiles of composers such as Ildebrando Pizzetti, Ottorino Respighi, or Francesco Malipiero.

Giuseppe Verdi's case is also significant in that, on the rare occasions when detailed articles were devoted to him, he was somehow portrayed as a predecessor of the Generazione dell'Ottanta and the ancient music revival, and was praised for his Requiem rather than for his operas. In his Requiem, according to José María Franco, the essence of Palestrina and ancient polyphony was to be found, and this made Verdi a pioneer of the revival of ancient music even in the times when bel canto reigned supreme. ${ }^{25}$

\section{The question of Italian opera in musical criticism}

Although theoretically opposed to the invasive influences of Italian opera, critics tended to react to actual operatic performances with an attitude that can be characterized as conformist; they rarely disclosed any of the prejudices found in the histories of music or other more general articles. The reviews of the opera seasons in Madrid almost completely dominated musical criticism during

\footnotetext{
${ }^{20}$ As described by Conrado del Campo in El Alcázar, 4/24/42.

${ }^{21}$ Arriba, 4/24/42.

${ }^{22}$ Pueblo, 4/24/42.

${ }^{23} A B C, 4 / 24 / 42$. The Generazione dell'Ottanta, whose most prominent members apart from Casella were Ildebrando Pizzetti and Francesco Malipiero, wished to eliminate the bel canto influences and create a new Italian music based on a more ancient Italian tradition.

${ }^{24}$ Radio Nacional, 6/15/41.

${ }^{25}$ Ya, 4/29/41.
} 
the one or two months in which Italian opera companies were in Spain. ${ }^{26}$ Critics did not usually choose to comment in detail on the musical or narrative aspects of the works performed. Rather conventionally, they focused on the vocal abilities of the divas and on the reaction of the audience, which was, almost invariably, one of enthusiasm and adulation. Music critics therefore seemed to have stepped into a "comfortable zone" in which Italian opera was tolerated because of its popularity and potential for use for financial and propagandistic aims. The underlying contradiction was, however, never addressed formally by musical critics, and traces of the prejudices against bel canto are minimal in the largely positive concert reviews of Italian performers visiting Spain. For instance, on the occasion of a German opera troupe's visit to Barcelona in early 1944, Antonio Fernández-Cid explicitly opposed the quality of the singers' performance to "those vain Italian opera divas, insensitive to the beauty of the music." ${ }^{27}$ Similarly, José María Franco judged Toti dal Monte's and Augusto Beuf's choice of repertory (mainly 19th-century Italian duets) for their recital in Madrid in 1942 as "not up to standard." 28

The regime itself, despite having founded its Institute of Musicology on the very basis of the ideas of Felipe Pedrell, a fierce opponent of Italian opera, did not even think of banning bel canto from the stages. Opera-or rather a reduced collection of 'opera standards,' which included Italian composers from Rossini to Puccini complemented by a limited number of French opéra bouffe successes-was a popular genre among Spanish audiences. In Madrid, despite the closure of Teatro Real between 1925 and 1926, operatic performances were accommodated in a number of other buildings such as the Teatro de la Zarzuela, the Teatro de la Comedia, or the Teatro Calderón. Opera seems also to be one of the few musical genres whose success in the early 1940s encouraged private companies to undertake the organization of opera cycles without necessarily being supported by the government or other institutions. The entrepreneur Barnes, for example, organized several events of this nature in Madrid during the 1940s. In contrast, German opera companies performing German repertoires seem to have had far less success with Spanish audiences: on the occasion of the performance of Ariadna auf Naxos by a German opera company at the Teatro del Liceu in Barcelona, critic Trape Pi complained that the work was not successful because of the "insensitiveness" of the audience. ${ }^{29}$

Unlike other genres, the popularity and accessibility of opera made it susceptible to being exploited for propagandistic aims directed at various social classes. In this regard, it is highly significant that the trade union Obra Sindical de Educación y Descanso chose opera to launch its series of 'Conciertos de Empresa' (literally 'Enterprise Concerts'). In the first concert, Educación y Descanso collaborated with its Italian equivalent, the Opera Nazionale Dopolavoro, to bring an ensemble of Italian and Spanish opera singers to the workshops of the electric company Standard Eléctrica. The program consisted of a selection of the most popular Italian arias. Thus, the lower classes could enjoy the singing of the Italian stars who were visiting Madrid for the opera season free

\footnotetext{
${ }^{26}$ The reviews, due to the fact that there was no opera theatre or company, were not distributed throughout the year but concentrated in the space of a few weeks.

${ }^{27}$ Arriba, 2/11/44.

${ }^{28}$ Ya, 11/22/42.

${ }^{20}$ Pueblo, 1/18/43.
} 
of charge, and at the same time, absorb something of the new diplomatic agenda of Spain suggested by the presence of Italian and Spanish authorities at the event.

Italian opera also demonstrated its important potential in assuring funds to support various sections of the governmental apparatus. Because foreign ensembles and soloists tended to attract larger audiences than local performers, their concerts were often organized as benefits and provided financial support for a variety of causes (for example, the war-wounded of the Spanish Civil War, or the armies fighting in World War II).

\section{Conclusions}

The end of the Spanish Civil War, the establishment of the Nuevo Estado, and the beginning of World War II had a powerful effect on the musical life of Spain. New cultural models had to be found within the Axis environment. Although Germany was the main generator of musical exchanges and the principal model for Spain during this time, the Italian tradition also played a role. In this context, musical critics undertook the role of developing a new rhetorical frame for exchanges with Italy. Critics did so partly by borrowing new concepts-mainly of racial natureforged by the ideologues of the Falange, and partly by reviving traditional ideas of Spanish musicology, especially those of Pedrell. The concepts of national and foreign and of traditional and modern, crucial in musical criticism of the time, also permeated the reception of exchanges with Italy.

It would be inaccurate, however, to assert that a coherent ideology-and still less a fascist ideology-was developed in order to place musical exchanges with Italy in the reality of the Nuevo Estado. In contemporary musical criticism, composers of the generation of Manuel de Falla with rather conservative ideas in regard to music (Joaquín Turina, Conrado del Campo, José Forns) coexisted with very young critics who reflected to some extent the ideology of the Falange (Federico Sopeña, Antonio Fernández-Cid), together with some figures who were not immediately identifiable to any of those groups (Joaquín Rodrigo). In addition, the newspapers and musical periodicals were also controlled by a number of entities, from the Falange to private companies or educational institutions. Although at times when pro-Axis sentiment surged in Spanish society, critics seemed to gear themselves toward a definite program (for example, on the occasion of Casella's visit), any attempt to reconstruct a complete fascist (or even only 'Francoist') ideology in their work would fall apart as a result of contradictory assertions or collapse for lack of evidence. In this context, it should be no surprise that some critics and newspapers regarded bel canto as the ruin of Spanish musical theatre tradition, but then enthusiastically reviewed the 19th-century operas staged in Madrid and other cities. This discrepancy was a consequence of the lack of a definite and consistently applied music policy, and reflects the necessity critics faced of having to adjust constantly to the changing political and diplomatic situation of the time. 


\begin{abstract}
The Spanish Civil War (1936-1939) put an end to the Second Republic and replaced it with an authoritarian, militarist, para-fascist regime commanded by General Francisco Franco. The musical life suffered the consequences of the struggle and, during the Second World War, exchanges with the Axis powers were used to revitalize it. This paper focuses on the exchanges with Italy and, specifically, how they were shaped by the musical press to fit the new ideological requirements of the Franco regime, which, on one hand, welcomed elements of racial theory (typical of fascism) to justify an essential unity between Italy and Spain based on the concept of Latinitas, but which was also extremely nationalistic and overzealous of foreign influences in Spanish music. The discourse of the Spanish musical press in regard to Italian music and musicians will be presented according to two pairs of contrasting concepts which were attributed different meanings and implications at different times: modern-traditional and national-foreign. This article seeks to make a contribution to the study of the interface between music and ideology in 1940s Spain from the point of view of the musical press, a critical source which has not been, so far, the central object of any study of this period.
\end{abstract}

